\title{
Institusi Inklusif Primum Non Nocere Kesejahteraan Sosial
}

\section{Primum Non Nocere Social Welfare Inclusive Institution}

\author{
Dadang Hartanto \\ Program Studi Administrasi Publik, Fakultas Ilmu Sosial \\ Universitas Muhammadiyah Sumatera Utara, Indonesia
}

Diterima: 29 Februari 2020; Disetujui: 28 Maret 2020; Diterbitkan: 01 Juli 2020.

\begin{abstract}
Abstrak
Model institusi yang bekerja dalam suatu negara dalam aspek ekonomi dan politik memberikan pengaruh terhadap kesejahteraan sosial. Pada model institusi inklusif hal prinsip yang harus dipegang adalah primum non necere atau fisrt do no harm bagi kesejahteraan sosial. Penyelanggara negara tidak boleh menyengsarakan kehidupan rakyatnya. Pada tulisan ini diperkuat bahwa politik dan ekonomi merupakan dua sisi mata uang yang mendorong dan mempengaruhi kesejahteraan sosial. Institusi inklusif selalu berhadapan dengan institusi ekstraktif. Daron Acemogle dan James A. Robinson (2012) dalam bukunya why nations fail mengungkapkan bahwa the economic growth and prosperity are associated with inclusive economic and political institutions, while extractive institutions typically lead to stagnation and poverty. Indonesia mempunyai peluang untuk memiliki instutusi ekstraktif oleh karena itu harus dicegah dengan mengimplementasikan demokrasi secara sungguh sungguh dan penegakan hukum yang indipenden berdasarkan due process of law. Institusi inklusif harus diwujudkan agar Indonesia dapat menjadi negara sehat dan kuat. kesehatan dan kekuatan suatu negara salah satunya ditentukan oleh kekuatan ekonominya yang memberikan kontribusi pada pembangunan dan penguatan fiskal. Fiskal dibangun salah satunya dengan meningkatkan penerimaan perpajakan karena kontribusi perpajakan terhadap fiskal rata - rata 77,6\%.

Kata Kunci: Ekonomi, Politik, Inklusif, Ekstraktif, System Thinking
\end{abstract}

\section{Abstract}

The institutional model that works in a country in economic and political aspects influences social welfare. In the inclusive institutional model the principle that must be held is primum non necere or fisrt do no harm for social welfare. Proponents of the state must not suffer the lives of their people. In this paper it is reinforced that politics and economics are two sides of a coin that encourage and influence social welfare. Inclusive institutions always deal with extractive institutions. Daron Acemogle and James A. Robinso (2012) in their book Why Nations Fails reveal that economic growth and prosperity are associated with inclusive economic and political institutions, while extractive institutions typically lead to stagnation and poverty. Indonesia has the opportunity to have extractive institutions and therefore must be prevented by implementing democracy seriously and independent law enforcement based on due process of law. Inclusive institutions must be realized so that Indonesia can become a healthy and strong country. One of the health and strength of a country is determined by its economic strength which contributes to development and fiscal strengthening. Fiscal is built one of them by increasing tax revenue because of the contribution of taxation to the fiscal average of $77.6 \%$

Keywords: Economy, Politics, Inclusive, Extractive, System Thinking

How to Cite: Hartanto, D. (2020). Institusi Inklusif Primum Non Nocere Kesejahteraan Sosial. PERSPEKTIF, 9(2): 119-129

*Corresponding author:

E-mail: dadanghartanto@umsu.ac.id 


\section{PENDAHULUAN}

The founding father negara Indonesia telah meletakkan kesejahteraan umum sebagai cita-cita luhur yang secara eksplisit terdapat dalam pembukaan Undang-Undang Dasar 1945. Kesejahteraan umum ini antara lain dapat dimaknai sebagai kesejahteraan sosial dimana berdasarkan Pasal 1 ayat (1) UndangUndang Republik Indonesia Nomor 11 tahun 2009, kesejahteraan sosial didefinisikan sebagai kondisi terpenuhinya kebutuhan material, spiritual, dan sosial warga negara agar dapat hidup layak dan mampu mengembangkan diri, sehingga dapat melaksanakan fungsi sosialnya.

Tingkat kesejahteraan sosial, berdasarkan perspektif ekonomi, diukur dengan berbagai parameter. Indonesia, sesuai paramater Indeks Pembangunan Manusia (IPM), berada pada angka 0,689, ada pada urutan 113 dari 188 negara1, pendapatan domestik (GNI) per-kapita berada pada posisi $10,25 \% 2$, tingkat pengangguran mencapai 5,333, serta angka kemiskinan Sebesar 27,77 juta orang $(10,64 \%)$, bertambah sebesar 6,90 ribu orang dibandingkan dengan kondisi September 2016 yang sebesar 27,76 juta orang $(10,70 \backslash \%) 4$, Gini Ratio sebesar 0.393 . (https://www.bps.go.id). Secara umum kesejahteraan dapat digambarkan dalam profil demografi Indonesia yang mengilustrasikan dominasi low class dan unfortunate people. Berikut gambaran kesejahteraan sosial menurut penghitungan dari boston consulting group:

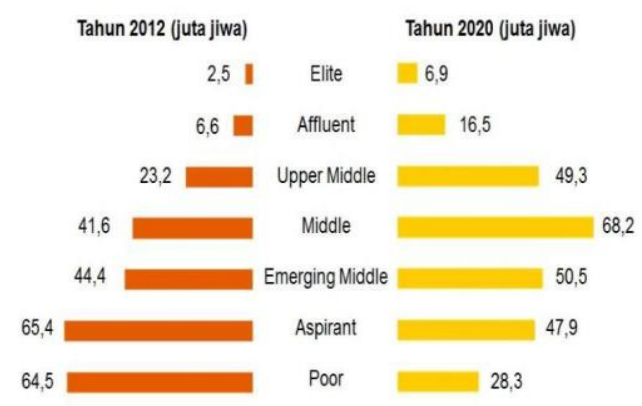

Gambar 1

Profil Demografi Berdasarkan Tingkat Pendapatan

Gambaran di atas menunjukan bahwa kesejahteraan sosial di Indonesia masih belum sepenuhnya sesuai dengan harapan. Namun perjuangan untuk mencapai kesejahteraan ini tidak pernah berhenti. Kekuatan ekonomi
Indonesia menjadi bagian penting dan menentukan pencapaian kesejahteraan tersebut. Kekuatan ekonomi tidak bisa dilepaskan dari berjalannya sistem ekonomi di suatu negara.

Elemen-elemen yang membentuk sistem ekonomi yang terus menjadi perhatian dan bahan kajian yaitu unit-unit ekonomi, pelaku ekonomi, sumber daya alam (SDA), sumber daya manusia, sumber daya kapital dan sumber daya teknologi. Elemen dalam ekonomi ini saling berinteraksi dalam hubungan fungsional sehingga menghasilkan capaian kondisi ekonomi. Pola interaksi dan fungsi masing-masing elemen diatur dalam suatu pranata yang keberadaanya sangat dipengaruhi oleh ideologi atau falsafah, pandangan dan pola hidup suatu masyarakat, bangsa dan negara.

Ideologi, falsafah, pandangan hidup menentukan konsep perpolitikan suatu negara dan konsep ini juga menentukan sistem ekonomi. Berdasarkan garis kontinum yang ditarik dari kanan ke kiri dapat diamati secara mendalam adanya dua kutub sistem ekonomi yang saling berseberangan yaitu antara liberalisme pada kutub sebelah kanan dan komunisme kutub sebelah kiri.

Paham liberalisme mengarahkan pada sistem ekonomi pasar. Sistem ekonomi ini digagas oleh Adam Smith dalam bukunya yang terkenal the wealth of nations (1776). Ide sentral buku ini adalah pasar bebas yang bergerak menurut mekanisme pasar akan mendorong produktifitas jumlah serta keberagaman barang dan jasa yang paling disenangi dan diperlukan masyarakat konsumen. Pemilihan terhadap suatu barang dan jasa didasarkan pada analisis seseorang terkait dengan keuntungan yang diperoleh dari barang dan jasa tersebut. Pada proses pencarian keuntungan dituntun oleh invisible hand. Secara umum, analisis keuntungan didasarkan pada suatu harga dari barang dan jasa. Tingkat pencarian atau permintaan (demand) dan ketersediaan barang dan jasa (supply) menentukan harga barang dan jasa tersebut. Harga secara alami akan mengikuti hukum pasar.

Invisible hand tidak akan bekerja apabila ada campur tangan pemerintah yang menentukan harga di dalam mekanisme pasar. Selanjutnya pada paham komunisme diberlakukan sistem ekonomi sosialis dimana 
ekonomi diatur oleh negara. Pada sistem ini pemerintah menentukan harga barang dan jasa apa yang akan diproduksi dengan cara atau metode bagaimana barang tersebut diproduksi, serta untuk siapa barang tersebut diproduksi. Sistem ekonomi ini lahir pada saat kemunculan tulisan Karl Marx yaitu Das Kapital (1867) dalam (https://www.marxists.org/indonesia/archive /marx-engels/1868/On-DKapital).

Indonesia sendiri menerapkan sistem ekonomi Pancasila. Sistem ekonomi ini bukan liberal - kapatitalistik juga bukan sistem ekonomi yang etatis namun menonjolkan nilainilai yang terkandung di dalam Pancasila. Masyarakat adalah bagian yang penting dimana kegiatan produksi dilakukan oleh semua untuk semua serta dipimpin dan diawasi oleh anggota masyarakat. Sistem ekonomi ini juga mengedepankan pemerataan ekonomi - kemakmuran rakyat yang utama bukan kemakmuran orang per orang.

Sistem ekonomi ini diharapkan memberikan dorongan jiwa bagi seluruh komponen bangsa dan negara Indonesia termasuk pemerintah yang dibentuk oleh kekuatan politik untuk mewujudkan kesejahteraan sosial. Pemerintah berkuasa, diperlukan komitmen untuk mengimplementasikan institusi inklusif dimana pengemban institusi ini sangat dituntut untuk menyadari dan menerapkan prinsip primum non nocere kesejahteraan sosial, yaitu penerapan prinsip yang menekankan bahwa hal pertama, utama dan penting dalam mengambil setiap keputusan, kebijakan dan tindakan serta langkah-langkah adalah jangan pernah membahayakan dan merugikan kesejahteraan sosial, menghambat berbagai upaya dalam mencapai kesejahteraan rakyat. Setiap penyelenggara negara tidak boleh menyengsarakan kehidupan rakyatnya.

Prinsip ini telah menempatkan dengan tegas bahwa politik dan ekonomi mempunyai korelasi yang sangat kuat. Politik dan ekonomi ibarat dua sisi mata uang. Arah umum kausalitasnya biasanya adalah dari politik ekonomi. Kebijakan ekonomi adalah penjabaran operasional dari tujuan politik yang lebih luas tetapi dalam kondisi tertentu dapat berlaku sebaliknya (Boediono, 2016). Acemoglu dan Robinson (2014) memiliki pandangan yang sama tentang kekuatan politik dalam memberikan pengaruh terhadap kondisi perekonomian. Pada buku tersebut secara umum, institusi politik yang inklusif mendukung tumbuhnya institusi ekonomi inklusif pula, sebaliknya institusi politik ekstraktif yang lebih mementingkan kelompoknya akan menciptakan institusi ekonomi yang ekstraktif.

Institusi ekonomi inklusif akan melahirkan suatu pranata yang memberikan akses kepada siapapun secara egalitarian untuk mendapatkan kesempatan menjalankan aktifitasnya bisnis dan ekonominya agar tumbuh dan berkembang mengejar keuntungan dan memberikan kontribusi bagi kesejahteraan sosial sedangkan institusi ekonomi ekstraktif melalui tangan penguasa dirancang pranata yang memodelkan suatu permainan agar sekelompok orang didunia ekonomi terlindungi dan mencegah munculnya pesaing sehingga sumberdaya dan keuntungan dapat diperoleh untuk kepentingan segelintir elit dan merugikan kesejahteraan rakyat secara umum.

Institusi ekonomi ekstraktif dapat menciptakan kesenjangan. Angka gini ratio dapat melebar tanpa adanya pemerataan aktifitas ekonomi. Keuntungan yang hanya didapat oleh para pelaku ekonomi ekstraktif cenderung dimanfaatkan untuk kepentingan diri dan kelompoknya serta memperkuat posisinya dalam jaringan kekuasaan yang mendukung praktik-praktik ekonomi ekstraktif yang telah dilakukannya. Kondisi tidak meratanya tingkat kesejahteraan baik pada tingkat individu maupun antara daerah serta didorong dengan isu negatif tentang ketidakadilan di bidang ekonomi dan dominasi ekonomi oleh kelompok etnis tertentu dapat memicu ketegangan, disharmoni dan konflik sosial.

Perspektif keamanan dalam negeri mengharuskan berbagai dinamika dan kompleksitas berbagai aspek yang ada dilingkungan sosial harus dapat diantisipasi termasuk dampak dari perkembangan dan implementasi model institusi ekonomi ekstraktif. Hal ini dilakukan agar kamdagri tetap terpelihara dan eksistensi NKRI tetap terjaga. Pada tulisan ini akan disajikan pembahasan tentang keberadaan institusi politik dan ekonomi serta pengaruhnya bagi kesejahteraan sosial dalam perspektif keamanan dalam negeri. 


\section{PEMBAHASAN}

\section{Hubungan Sistemik Antara Keamanan, Politik Dan Ekonomi (Analisis Berdasarkan System Thinking)}

Perkembangan dunia yang begitu kompleks dan dinamis memerlukan suatu perspektif yang komprehensif dan holistik untuk memahaminya. Sterman (1996) memandang bahwa untuk memahami karakteristik perkembangan lingkungan yang demikian ini memerlukan suatu cara pandang yang disebut dengan system thinking (berpikir serba sistem) "the ability to see the world as a complex system, in which we understand that "you can't just do one thing" and that "everything is connected to everything else".

Perlu dipahami lebih jauh bahwa sistem ini memandang dunia atau lingkungan sebagai sesuatu kejadian yang saling terkait (connect) satu dengan yang lain membentuk pola tertentu dan masingmasing kejadian mempengaruhi kejadian lainnya. Suatu kejadian tidak dilihat sebagai suatu kejadian yang berdiri sendiri, tetapi dilihat saling terkait dalam pola tertentu. Perspektif berpikir serba sistem sangat penting untuk digunakan dalam melihat keterkaitan antara dunia ekonomi, politik, kesejahteraan dan keamanan agar realitas yang tampak dapat menjadi landasan untuk mengambil tindakan dan antisipasi berbagai hal yang dapat merugikan kehidupan bangsa dan negara. Berikut gambaran keterkaitan antara ekonomi, politik, kesejahteraan dan keamanan yang terhubung secara sistemik

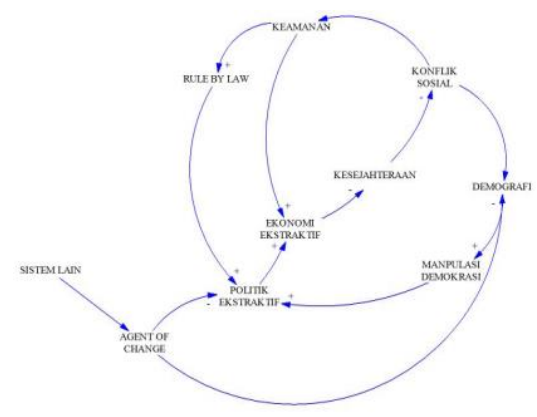

Gambar 2

Dunia Ekonomi Ekstraktif Dalam Perspektif System Thinking

Sumber: Data Diolah Penulis, 2017

\section{Hubungan Ekonomi dan Kesejahteraan}

Secara umum telah dipahami bahwa ekonomi dapat memberikan pengaruh pada tingkat kesejahteraan. Model ekonomi yang perlu diwaspadai adalah berkembangnya ekonomi ekstraktif. Ekonomi yang dikembangkan hanya untuk kepentingan kelompok tertentu dengan menggunakan kekuatan negara. Pelakupelaku ekonomi ekstraktif menggunakan kekuasaan negara (dirigisme), melalui tangan pemegang kekuasaan untuk mendukung kelancaran bisnisnya. Ketika model ekonomi ini berkembang maka kesejahteraan sosial akan terancam. Pola hubungan antara ekonomi ekstraktif dan kesejahteraan sosial bersifat negatif. Pertumbuhan ekonomi ekstraktif menyebabkan kesejahteraan sosial menjadi sulit dicapai karena ekonomi ekstraktif cenderung menyebabkan gini ratio meningkat, yaitu kesenjangan pendapatan antara golongan atau perbedaan si kaya dan si miskin semakin lebar.

\section{Hubungan Kesejahteraan dan Konflik Sosial}

Kondisi kesejahteraan sosial yang rendah ditandai dengan tingginya tingkat kemiskinan, pengangguran dan kesenjangan sosial (gini ratio) dapat merapuhkan hubungan dan harmonisasi kehidupan sosial. Ketika sekat-sekat semakin tajam antara si kaya dan si miskin, meluasnya kecemburuan sosial serta persepsi negatif yang tinggi dipicu oleh harapan low class untuk dapat memenuhi kebutuhan hidupnya, ditengah berbagai tampilan gemerlapnya dunia yang tidak mampu ia jangkau, sementara negara belum sepenuhnya dapat hadir membela kepentinganya maka potensi konflik sosial akan tinggi dan mudah terbuka dan pecah menjadi kejadian nyata yang mendegradasi kualitas keamanan dan ketertiban di lingkungan masyarakat. 


\section{Hubungan Keamanan, Ekonomi dan Hukum}

Kualitas keamanan yang buruk akan menimbulkan keengganan investasi sehingga dapat memperburuk pertumbuhan ekonomi dan PDB. Hal ini tentu tidak dapat dibiarkan, kekuatan politik ekstraktif akan menjaga agar ekonomi tetap berjalan dengan memperkuat kedudukan para pelaku ekonomi ekstraktif. Keamanan terus dilakukan perbaikan terutama diarahkan untuk memperkuat posisi politik ekstraktif.

Aktor keamanan dapat dijadikan alat untuk menjaga kepentingan pelaku politik ekstraktif dengan mempraktekan rule by the law bukan rule of the law, memerintah dengan menggunakan hukum, bukan berdasarkan hukum. Kekuatan hukum dijadikan alat untuk melindungi kepentingan selain kepentingan hukum, yaitu kepentingan kelompok institusi ekstraktif yang keberadaanya kembali menimbulkan kesenjangan dan membuka konflik sosial. Kondisi situasi konflik menyulitkan masyarakat untuk membangun kegiatan ekonomi guna meningkatkan pendapatan sehingga masyarakat kelas bawa semakin besar dan mendominasi profile demografi. Hal ini berarti bentuk profile demografi semakin berbentuk pyramid.

Belajar dari revolusi sosial di Perancis pada 1787-1789 dipicu oleh ketidakadilan antar kelas yang dilakukan oleh negara sebagai kelompok dominan. Prancis saat sebelum revolusi lebih mencerminkan rule by law dari pada rule of law. Ketidakadilan yang disebabkan oleh pengaturan hukum yang tidak berpihak kepada rakyatnya mengakibatkan adanya gejolak sosial yang menuntut adanya keadilan hukum menuju keadilan ekonomi. Revolusi ini terjadi ketika fungsi hukum didalam masyarakat bekerja tidak mencapai nilai dasar atau tujuan hukum yang diharapkan masyarakat.
Radbruch (1961), menyampaikan ada tiga nilai dasar atau tujuan hukum yaitu Keadilan, kemanfaatan dan Kepastian hukum. Diantara Ketiga nilai dasar hukum terdapat spannungsverhaltnis, yaitu suatu ketegangan antara satu dengan lainnya yang memiliki potensi saling bertentangan. Apabila salah satu di antara nilai tersebut dikedepankan, maka akan menggeser dua nilai yang lain ke samping. Hal ini disebabkan karena masing-masing nilai tersebut, memiliki tuntutan yang berlainan satu dengan lainnya, dan mengandung potensi saling berhadapan.

Kepastian hukum seringkali ditonjolkan dan menjadi alat untuk membenarkan berbagai kepentingan. Pada kondisi ini hukum dapat masuk ke wilayah yang berbahaya, yakni membenarkan kepentingan yang melawan keadilan masyarakat, termasuk berbagai hal yang kurang berguna bagi rakyat (Nitibaskara, 2006).

\section{Hubungan Kesejahteraan, Demokrasi dan Politik}

Masyarakat kelas bawa yang belum sejahtera disertai tingkat pendidikan yang belum memadai menjadi ladang yang subur untuk memanfaatkannya menuju arah tertentu yang dimotivasi dengan pemberian materi dan kebutuhan lainnya. Praktik eksploitasi masyarakat kelas bawa menjadi semakin kuat pada masyarakat berkarakteristik komunal dan memiliki ikatan hubungan patron - klien. Patron yang merupakan significant others menjadi figur yang menjadi sasaran untuk dikendalikan guna mendapatkan kekuatan para klien. Praktik eksploitasi masyarakat dan menggerakannya dengan menyentuh kelemahan yang dimilikinya pada aspek kesejahteraan dan pendidikannya, pada era demokrasi telah diwujudkan antara lain dalam pemilu. Peneliti ICW, Abdullah Dahlan mengungkapkan beragamnya modus politik uang yang telah dimodifikasi, baik berbentuk barang jasa, asuransi 
(http://www.kantorberitapemilu.com/rea d/2017/10/14/6076/Politik-Uang-TelahDimodifikasi).

Manipulasi demokrasi ini dapat menghasilkan politik ekonomi ekstraktif. Pada lingkup lokal di Indonesia, fenomena itu nampak ketika pemilu kadang menghasilkan dan mengembangkan politik dinasti pada beberapa daerah. Kepala daerah dapat berganti dari Suami ke Istri, saudara dan orang-orang yang memiliki kedekatan dengan pemilik kekuasaan. Pemilik kekuasaan telah mengetahui sumber-sumber untuk mendapatkan suara dengan memanfaatkan kekuatan yang dimilikinya meskipun dengan cara transaksional. Hal ini tentu akan memperkuat politik ekstraktif yang menghasilkan institusi, kebijakan dan keputusan serta pelaksanaan penyelenggaraan negara yang ditujukan untuk mengamankan kepentingan kelompoknya.

\section{Hubungan Agent of Change dan Politik}

Indonesia berpeluang mengalami lahirnya institusi ekstraktif yang dimotori oleh pelaku ekonomi dan politik ekstraktif. Pencegahan harus dilakukan, system yang mempunyai kekuatan balancing harus dihadirkan dan diperkuat yang menghasilkan para agent of change, like mind people atau orang satu visi dalam mengelola masa depan bangsa. Orangorang ini harus dapat masuk dalam setiap lingkungan sosial. Memberikan virus perubahan, menguasai pusat kekuasaan untuk mengambil keputusan dan kebijakan yang berorientasi pada kepentingan bangsa dan negara. Sistem tersebut dapat berupa pembangunan dunia pendidikan yang memberikan kepada siapa saja yang mempunyai kemampuan untuk mencapai level pendidikan tertinggi meskipun seseorang memiliki keterbatasan dalam bidang ekonomi.

Manajemen pembiayaan dengan beasiswa dan pinjaman yang ringan dapat menyentuh kebutuhan biaya bagi pendidikan anak bangsa terutama yang berkualitas outstanding.

Pada bidang politik, kekuatan penyelenggara pemilu mempunyai posisi yang sentral dalam menentukan lahirnya pemegang kekuasaan politik yang bersifat inklusif. Kekuasaan yang benar-benar memegang prinsip primum non necere kesejahteraan sosial merupakan suatu prinsip yang harus diterapkan dalam penyelenggaraan suatu negara. Hal ini dimaknai sebagai Kebijakan, program, kegiatan dan keputusan yang diambil oleh setiap penyelenggara negara tidak boleh membahayakan kesejahteraan rakyat atau menyengsarakan kehidupan rakyat.

Keberadaan penyelenggara pemilu yang mandiri dengan kekuasaan penegakan hukum yang independen perlu dibentuk dan diperkuat, karena sangat disadari urusan permasalahan politik tidak terlepas dari tarik menarik kepentingan dan melibatkan berbagai pihak yang berkuasa. Mesin politik yaitu partai politik diharapkan dapat menjadi institusi yang menghasilkan pemimpin dan menciptakan regenerasi bagi pemimpin masa depan yang akan membawa negara ini dengan kesungguhan mencapai masyarakat aman, adil, makmur dan sejahtera. Indonesia telah berada pada track ini meskipun dalam perjalannya mengalami berbagai kelemahan dan kendala.

\section{Institusi Inklusif dan Institusi Ekstraktif}

Pada analisis hubungan berdasarkan system thinking di atas sesungguhnya dampak sistemik tersebut disebabkan adanya pertarungan antara institusi inklusif dan institusi ekstraktif. Institusi inklusif merupakan pengelolaan dan pengaturan dalam penyelenggaraan kehidupan berbangsa dan bernegara yang ditujukan untuk kepentingan rakyat dan berorientasi kepada kemajuan negara serta melibatkan rakyat untuk ikut berpartisipasi dan melakukan pengawasan dalam pencapaiannya sedangkan institusi 
ekstraktif adalah pengelolaan dan pengaturan dalam penyelenggaraan kehidupan berbangsa dan bernegara yang hanya ditujukan untuk mewujudkan dan melindungi kepentingan kelompok tertentu dan membatasi keterlibatan rakyat dalam pelaksanaanya. Kedua model Insititusi diatas mencakup bidang politik dan ekonomi. Bidang politik sangat erat kaitanya dengan kekuasaan atas kendali dalam penyelenggaraan pemerintahan sedangkan ekonomi pada penguasaan sumber daya pada kebutuhan hidup manusia.

Lebih jauh lagi dapat dijelaskan bahwa institusi politik inklusif dipandang sebagai pranata dan lembaga yang menjalankan kekuasaan dengan membagi dan memberi kesempatan pada rakyatnya untuk berpartisipasi, mengkontrol dan menentukan arah dan upaya untuk mencapai tujuan berbangsa dan bernegara sedangkan institusi politik ekstraktif lebih menekankan pada kekuasaan yang tidak memberikan atau membatasi kesempatan rakyatnya untuk berpartisipasi dan mengkontrol pelaksanaan kekuasaan tersebut.

Institusi politik inklusif secara umum dijalankan oleh pemerintahan demokrasi dan menjunjung supremasi hukum sebaliknya institusi politik ekstraktif dihasilkan dari pemerintahan yang bersifat otoriter. Kedua model institusi politik ini memberikan pengaruh pada lahirnya institusi ekonomi yang menimbulkan dampak pada kesejahteraan sosial. Acemoglu dan Robinson (2014) menyatakan suatu tesis terkait kedua model institusi politik ini yaitu "the economic growth and prosperity are associated with inclusive economic and political institutions, while extractive institutions typically lead to stagnation and poverty".

Tesis ini diperkuat dengan suatu penelitian empiris pada kesenjangan yang terjadi diantara dua sisi pada tapal batas kota Nogales. Sisi utara dari tapal batas kota nogales berada pada wilayah Arizona, salah satu negara bagian Amerika dan sisi selatan berada pada wilayah Sonara dibawa kekuasaan negara Mexico.

Kondisi kedua sisi ini memiliki disparitas yang sangat mencolok dimana Nogales, AS hidup sangat sejahtera, pendapatan perkapita $\$ 30.000$ dengan fasilitas kesehatan, pendidikan, publik dan keamanan yang terjamin sedangkan warga kota Nogales, Sonara, Meksiko, memiliki pendapatan parkapita sepertiga dari warga kota Nogales Amerika, kualitas penyelenggaraan pendidikan yang rendah, jaminan kesehatan yang tidak mencukupi ditandai dengan angka kematian bayi yang tinggi serta tingkat keamanan yang perlu peningkatan dalam menghadapi angka kejahatan yang tinggi.

Kesenjangan ini terjadi karena perbedaan institusi politik dan ekonomi. Perbedaan pada institusi ini mengakibatkan perbedaan insentif yang diberikan kepada perusahaan, perorangan dan politisi sebagai contoh studi komperatif Institusi politik yang bekerja di US dan Mexico. Negara US memiliki Bill Gates sebagai manusia terkaya didunia dan pendiri perusahaan teknologi yang paling inovatif, namun ketika Bill Gates menghadapi permasalahan hukum terkait tuduhan monopoli, ia tidak dapat mengatasi Departemen Kehakiman Amerika Serikat membawanya ke sidang class action terhadap Microsoft tahun 1998. Hakim memutuskan microsoft melanggar hukum persaingan usaha AS.

Institusi yang bekerja di wilayah US berbeda dengan di Mexico dalam memberikan perlakuan terhadap warga negaranya. Negara Mexico, melalui lelang menjual perusahaan Telekomunikasi "Telmex". Grup Corso yang dipimpin Carlos Slim memenangkan lelang meskipun bukan penawar tertinggi. Saham yang dibelinya tidak dibayar langsung secara lunas namun dibayar hasil dividen dari Telmex. Telmex menjadi monopoli miliki perorangan. Tahun 1996 Avantel 
mengajukan tuntutan ke komisi persaingan usaha meksiko tetapi kandas. Bisnis di Meksiko memiliki faktor pembeda yaitu ada tokoh penguasa yang dikenal dan bisa dipengaruhi serta bisa disuap untuk mendapatkan keuntungan bersama.

Namun ketika Carlos Slim melebarkan sayap bisnis ke Amerika Serikat. Slim membeli perusahaan CompUSA dan memutuskan kontrak yang sudah dijalin oleh perusahaan COCservices. Perusahaan ini menuntut dan menang. Slim harus membayar \$454 Juta. Slim tidak mempunyai kekuatan dalam aturan permainan (hukum) yang ditetapkan di Amerika Serikat.

Acemoglu dan Robinson (2014) juga menyatakan bahwa institusi ekstraktif akan melahirkan kesengsaraan terhadap rakyatnya tidak selamanya terjadi. Ada beberapa kasus khusus yang kekuatan politik ekstraktif menghasilkan ekonomi inklusif dan menciptakan kesejahteraan sosial sebagaimana di Korea Selatan, Jenderal Park berkuasa lewat kudeta militer pada tahun 1961. Meskipun bergaya otoriter pemerintahan Jenderal Park aktif merangsang pertumbuhan ekonomi negara.

Kasus lainnya adalah negara Tiongkok. Negara ini pernah mengalami kemiskinan paling para dalam peradaban. Pada tahun 1990, Deng Xiao Ping seorang pemimpin revolusi dalam Partai Komunis Tiongkok yang menjadi pemimpin tertinggi Republik Rakyat Tiongkok pada kurun waktu 70-an sampai dengan awal dasawarsa 90-an mencetuskan reformasi China yang disebut dengan Gaige Kaifang (reformasi dan keterbukaan). Reformasi tersebut sering disebut The Four Modernizations. Empat pilar empat modernisasi itu adalah Reformasi Pertanian, Industri, Teknologi dan Pertahanan.

Kemajuan ekonomi di Tiongkok yang pesat dikarenakan mengadopsi sistem ekonomi kapitalis namun disertai kontrol yang kuat oleh negara untuk mewujudkan kemakmuran bagi seluruh rakyat Tiongkok. Tiongkok juga semakin maju karena didukung oleh regenerasi pemimpin yang kuat dan memiliki komitmen pada rakyatnya. Pada komitmen tentang pemberantasan korupsi misalnya pernyataan perdana menteri Tiongkok Zhu Rongji (1998) yang melegenda yaitu "Beri saya 100 peti mati, 99 akan saya gunakan untuk mengubur para koruptor, dan 1 untuk saya kalau saya melakukan tindakan korupsi".

Keberlangsungan suatu institusi politik apapun bentuk modelnya sangat ditentukan oleh eksistensi pemimpinnya dalam memberikan dampak pada terwujudnya kesejahteraan dan kemajuan suatu negara. Korea selatan dan Tiongkok sangat beruntung memiliki pemimpin yang tidak bekerja dan memanfaatkan posisinya untuk kepentingan diri dan kelompoknya.

Pada konteks di Negara Indonesia, sejarah dibidang ekonomi mencatat Indonesia mengalami pasang surut pertumbuhan ekonomi yang dinamis. Pasca proklamasi kemerdekaan dan pengakuan kedaulatan, konsolidasi politik dan ekonomi dilakukan. Pada kurun waktu tertentu, Indonesia pernah memiliki prestasi ekonomi menonjol dengan berbagai indikator kesejahteraan sosialnya menunjukan kemajuan nyata. Namun dibawa permukaan ada perkembangan yaitu kestabilan politik yang sangat diperlukan bagi kebijakan ekonomi dan pembangunan yang efektif ternyata mempunyai dampak sampingan, yaitu terjadinya kepengapan politik dan berkembangnya kronisme (Boediono, 2016).

Pelaku ekonomi ekstraktif yang mendapat perlindungan dari penguasa mulai bermunculan dan menanamkan jaringan ekonominya hingga mendapatkan keuntungan yang berlipat bagi diri dan kelompoknya sementara proses checks and balances tidak berjalan sebagaimana yang diharapkan. 
Keterbatasan rakyat untuk berpartisipasi dalam bidang Politik yang secara laten menginginkan suatu perubahan menemukan momentumnya saat terjadi krisis 1997 dan 1998. Kekuatan laten menjadi gerakan politik nyata yang menuntut demokratisasi, desentralisasi dan transparansi. Indonesia memasuki era reformasi dengan politik dan aturan main yang baru. Nampaknya gelombang ke tiga demokratisasi sebagaimana yang diungkapkan oleh Samuel P. Hungtington dialami di Indonesia (Huntington, 1994).

Ia menyatakan Demokratisasi gelombang ketiga yang dimulai pada tahun 1974 memiliki penyebab yang sangat kompleks antara lain melemahnya legitimasi rezim otoriter, perkembangan di sektor ekonomi dimana Indonesia berada pada krisis ekonomi ditandai salah satunya dengan nilai tukar rupiah terhadap dollar Amerika yang semula Rp 2600 per dollar mencapai hingga Rp.17.000, dampak dari perubahan politik dibeberapa kawasan (snowball effect) yaitu terjadinya perubahan politik di negara-negara blok timur, dan tekanan dari luar sebagaimana pasca kemenangan perang dingin oleh dunia barat yang ingin mengimpose paham demokrasi ke negara-negara lain.

Namun apakah Indonesia telah menemukan "a workable democracy", demokrasi yang dapat berfungsi menjamin stabilitasi politik dan terpeliharanya kesatuan dan persatuan bangsa serta mendorong pemerintah mampu menjalankan fungsinya secara maksimal untuk memberikan pelayanan dan perlindungan yang maksimal kepada masyarakatnya. Fenomena yang nampak menunjukan Indonesaia masih mengalami transisi demokrasi, (Gaffar, 2000) menyatakan:

"Proses perubahan sosial yang berjalan selama sepermpat abad diharapkan memunculkan kelas menengah di Indonesia yang secara teoretik akan membantu proses demokratisasi menuju sebuah kehidupan politik yang demokratik. Namun kenyataanya, kelas menengah masih terlampau sedikit untuk berperan dalam sebuah demokrasi. Kelas menengah biasanya adalah kelompok masyarakat yang pada umumnya mandiri dan terbebas dari kekuasaan negara dengan demikian kelompok inilah yang akan menjadi bumper bagi masyarakat agar negara tidak menjalankan kekuasaanya secara berlebihan, namun hal itu masih belum terjadi di Indonesia".

Berdasarkan pandangan Gaffar ini maka dengan memahami profile demografi Indonesia yang didominasi oleh low class, low educated dan unfortunate people, maka praktek demokrasi di Indonesia yang diharapkan dapat menghasilkan institusi politik inklusif masih memerlukan penguatan karena pada perkembangannyademokrasi dimanipulasi oleh kekuatan yang memiliki kekuasaan dibidang politik, ekonomi dan media.

(http://www.antaranews.com/berita/615 888/pihak-pihak-yang-memanipulasirakyat-menurut- kepala-kepolisianindonesia)

Kekuatan pelaku ekonomie kstraktif memiliki kekuatan untuk menentukan institusi politik saat ini. Beberapa

fakta menunjukan demokrasi yang berlangsung di Indonesia diwujudkan dalam pemilu Kepala Daerah, Legislatif dan Presiden/Wakil Presiden masih diwarnai money politik, black campaign dan pemanfaatan media sosial untuk mendiskriditkan lawan politik dengan berbagai isu termasuk isu SARA yang dapat memecah persatuan dan kesatuan. Kemenangan pihak dari pelaku ekonomi ekstraktif dapat menurunkan kualitas institusi politik inklusif, karena pemenang akan dikendalikan dalam suatu mekanisme politik transaksional.

Memahami kondisi tersebut, politik demokrasi dalam perspektif keamanan dalam negeri menuntut penegakan hukum yang berlandaskan "due process of law" yaitu kekuatan penegakan hokum yang didasarkan pada keadilan dan 
kebenaran. Pada implementasinya, penegakan hukum akan sangat sulit dilakukan terutama menghadapi kekuatan politik yang mengkooptasi hukum itu sendiri.

Sistem hukum dalam kaitannya dengan kasus yang berlatar belakang politik dapat dirancang secara tepat sehingga menghasilkan penegakan hukum yang independen. Selain itu, para cendikiawan dan pemikir idealis yang biasanya lahir dari lingkungan pendidikan dan akademisi diharapkan berperan aktif menekan terjadinya penyimpangan, mengawasi proses penegakan hukum, menciptakan sistem berdemokrasi yang baik dan mengembalikan demokrasi "on the right track".

"Negara Sehat, rakyat sejahtera" perlu menjadi tag line bagi penyelenggara negara yang berkomitmen untuk membangun institusi inklusif. Negara yang sehat tercermin dari keberadaan fiskal yang sehat dan kuat yang berarti berarti ketersediaan keuangan negara yang memadai bahkan melebihi yang diharapkan dalam mendukung belanja negara. Komposisi kebutuhan anggaran yang harus didukung dengan kekuatan fiskal meliputi mandatory spending (pengeluaran yang sudah ditetapkan oleh Undang-Undang), Non-discretionary spending (belanja terikat) dan belanja tidak terikat atau ruang fiskal (fiskal space).

Fiskal yang sehat dan kuat juga memerlukan ruang fiskal yang lebar yaitu ketersediaan ruang dalam anggaran lebar sehingga memampukan pemerintah menyediakan dana untuk tujuan tertentu (prioritas pembangunan) tanpa menciptakan permasalahan dalam kesinambungan posisi keuangan pemerintah http://www.dpr.go.id/doksetjen/dokumen/ap bn_Ruang_Fiskal_APBN20130130094655).

Ruang fiskal merupakan anggaran diskresioner, dengan demikian, ruang fiskal menjadi ukuran fleksibilitas pemerintah dalam mengalokasikan anggaran didalam APBN. Ruang fiskal memerlukan kebijakan fiskal yang tepat dalam hal kebijakan pendapatan (taxation/revenue policy), kebijakan belanja (spending/expenditure policy) dan kebijakan pembiayaan atau kebijakan utang (financing/debt policy).

Penerapan kebijakan ini harus memperhatikan solvabilitas keuangan jangka panjang sebagai kemampuan fiskal dalam menjalankan fungsi distribusi, alokasi, dan stabilisasi. Kebijakan fiskal yang tepat juga mencerminkan kinerja dalam pembangunan fiskal dan hal ini memerlukan kebijakan fiskal yang kredibel yaitu: pertama; mampu membuat kondisi perekonomian berubah menjadi lebih baik, kedua; mampu mengendalikan atau mengantisipasi risiko fiskal, seperti risiko utang, risiko defisit anggaran dan ketiga; mampu menjaga kepercayaan publik yang digambarkan dari angka-angka dalam APBN yang rasional baik dari sisi penerimaan, belanja maupun pembiayaan (utang).

APBN sebagai instrument kebijakan fiskal pemerintah yang disusun dengan mempertimbangkan asumsi pertumbuhan ekonomi, inflasi dan tingkat bunga Surat Perbendaharaan Negara (SPN), nilai tukar rupiah, harga minyak mentah per barrel, lifting minyak perbarrel dan lifting gas per-barrel. Pemerintah telah berpengalaman dalam menghadapi risiko fiskal. Rasio defisit misalnya harus dijaga berada dibawah threshold yang telah ditetapkan dalam Undang-Undang Keuangan Negara yakni maksimum 3\% dan total hutang tidak boleh melebihi $60 \%$ dari PDB (pasal 12 ayat 3 Undang - Undang 17 tahun 2003 tentang Keuangan Negara). APBN tidak boleh mengalami risiko default. Pemerintah tidak boleh selalu mengandalkan utang dalam mengatasi risiko tersebut, namun harus lebih ditekankan pada upaya memperkuat pembangunan fiksal.

Pembangunan maupun penyelamatan fiskal memerlukan tingkat penerimaan negara yang memadai 
terutama dari sektor perpajakan. Penerimaan perpajakan ini memberikan pengaruh signifikan pada pembangunan fiskal yang berkorelasi langsung dengan kondisi APBN yang sehat dan sustainable. Berdasarkan data Kemenkeu tahun 2017 bahwa penyumbang terbesar penerimaan negara adalah sektor perpajakan. Rata-rata penerimaan perpajakan menyumbang 77,6\% dari APBN (Data APBN tahun 2017 85,6\%). Namun demikian besarnya anggaran yang dihimpun dari sektor perpajakan masih belum optimal.

\section{SIMPULAN}

Indonesia mempunyai peluang untuk memiliki institusi ekstraktif oleh karena itu harus dicegah dengan mengimplementasikan demokrasi secara sungguh - sungguh dan penegakan hukum yang indipenden berdasarkan due process of law. Institusi inklusif harus diwujudkan agar Indonesia dapat menjadi negara sehat dan kuat. kesehatan dan kekuatan suatu negara salah satunya ditentukan oleh kekuatan ekonominya yang memberikan kontribusi pada pembangunan dan penguatan fiskal. Fiskal dibangun salah satunya dengan meningkatkan penerimaan perpajakan karena kontribusi perpajakan terhadap fiskal rata - rata $77,6 \%$.

\section{DAFTAR PUSTAKA}

Acemoglu, D. and Robinson, J.A. (2014) Why Nations Fail: The Origins of Power, Prosperity, and Poverty, Public Choice 159(12):317-320

Boediono. (2016). Ekonomi Indonesia Dalam Lintasan Sejarah. Bandung: PT Mizan Pustaka.

Boediono. (2016). Ekonomi Indonesia: Dalam Lintasan Sejarah. Jakarta: Mizan,

Gaffar, A. (2000). Politik Indonesia Transisi Menuju Demokrasi. Yogyakarta : Pustaka Pelajar,

http://www.antaranews.com/berita/615888/pihakpihak-yang-memanipulasi-rakyat-menurutkepala-kepolisian-indonesia. n.d.

http://www.dpr.go.id/doksetjen/dokumen/apbn_Ru ang_Fiskal_APBN20130130094655. n.d.

http://www.kantorberitapemilu.com/read/2017/10 /14/6076/Politik-Uang-Telah-Dimodifikasi.

http://www.pajak.go.id/sites/default/files/LAKIN \%20DJP\%202016

https://www.bps.go.id. n.d.

Huntington, S.P. dan Nelson, J. (1994). Partisipasi Politik di Negara Berkembang. Jakarta: Rineka Cipta.

Nitibaskara R, Wibowo S, dan Uju. (2006). Penanganan dan Transportasi Ikan Hidup untuk Konsumsi. Departemen Teknologi Hasil Perairan, Fakultas Perikanan dan Ilmu Kelautan, IPB. Bogor

Radbruch, G. (1961). Einfuehrung In Die Rechtswissenchaft. Koehler Verlag, Stuttgart.

Sterman, J. (2000), Business Dynamics, System Thinking and Modeling for a Complex World 